\title{
THERMAL MINERAL WATERS OF VOJVODINA (SERBIA) AND THE POSSIBILITY OF THEIR USE - A CASE STUDY OF THE MUNICIPALITY OF KIKINDA
}

\author{
Milka Bubalo-Živković1*, Tamara Lukić*, Bojan Đerčan*, Rastislav Stojsavljević*, \\ Dajana Bjelajac*, Branko Ristanović*
}

* University of Novi Sad, Faculty of Sciences, Trg Dositeja Obradovića 3, 21000, Novi Sad, Serbia

\begin{abstract}
On the territory of Vojvodina in the period from 1969 to 201078 boreholes were drilled for the purpose of finding thermal mineral water. Serbian part of Banat in Vojvodina has 18 boreholes, most of which in the municipality of Kikinda (six). All boreholes reach first hydro geological system. The geothermal gradient in the municipality of Kikinda is in the range of 0.052 to $0,057^{\circ} \mathrm{Cm}-1$, and the density of terrestrial heat flow is of $94 \mathrm{mWm}-2$ to $105 \mathrm{mWm}-2$, which is significantly more than in the area of the continental part of Europe. Thermal mineral waters in the wells in the municipality of Kikinda are hypothermal, with favorable mineralization, $\mathrm{pH}$ and salinity, which enable various possibilities of use. The waters have been used for heating needs of business premises and pig farm. However, in addition, water can be used in balneological purposes, for sports and recreation, agriculture, industry. Thermal mineral water found in the municipality of Kikinda can have a huge part in regional development, but also attract investors from our country and abroad. However, financial and administrative problems are just some of the restrictions when creating or implementing studies for the use of thermal mineral water in the municipality of Kikinda.
\end{abstract}

Key words: Kikinda, thermal mineral water, the possibility of using thermal mineral waters

1 Corresponding author: M. Bubalo-Živković, University of Novi Sad, Faculty of Sciences, Novi Sad, Serbia; e-mail: milka.bubalo.zivkovic@dgt.uns.ac.rs 


\section{Introduction}

A huge amount of heat energy is accumulated in the outer ten kilometers of the earth's crust (Nakomcic-Smaragdakis et al., 2016), which could be used and meet the needs of mankind for thousands of years. Only a small part, and only in certain areas, can be used because of its diffuse spreading. Zones on Earth with great geothermal potential, are related to the phenomena of volcanism and active seismic areas, that it to the peripheral zones of continental plates (Bubalo and Bogdanović, 2000). In such zones water vapor and high thermal waters are frequent occurrences. Beside these areas, to obtain thermal mineral water of lower temperature, interesting areas are deep sedimentary basins, such as the Pannonia Basin, which geologically belongs to the whole Vojvodina (Aksin and Milosavljević, 1982). Geothermal energy is a form of renewable energy sources (Ivić et al., 2002) and is considered environmentally clean (Lukić et al., 2014). The consumption of renewable energy has a significant impact on economic growth, especially in those countries that do not have oil reserves (Kocsis et al., 2015). The use of thermal mineral water, or water vapor and hot water, for energy purposes (called geothermal energy) is driven by the energy crisis and the uneven distribution of conventional energy resources in the world. The first use of geothermal energies are related to the production of electricity in Italy, New Zealand, USA, Mexico, Japan, Iceland, Russia and others (Milosavljević, 1994).

Serbia is very rich in thermal mineral waters which represent its natural and national treasure. Many of them are used for centuries, mostly in balneology. In terms of the number, diversity and quality many mineral and thermal waters are very rare in the world (Belij and Belij, 2009). On the territory of Serbia there are natural thermal mineral springs that are among the hottest in Europe (Vranjska spa - over $100{ }^{\circ} \mathrm{C}$, Jošanička spa - about $78^{\circ} \mathrm{C}$, Sijarinska spa $72^{\circ} \mathrm{C}$ ) (Radičević, 2008) but these waters are insufficiently used in Serbia.

Mineral and thermal waters in the territory of Serbia, and the Pannonia Basin, have been known since the Roman period. The first scientific knowledge of the geological structure and hydrological conditions date from the 19th century which were performed by geologists in Hungarian state institutions. It is precisely in the area of Banat where the first drillings of artesian wells were done in the mid $19^{\text {th }}$ century (Pavliš near Vršac, Banatski Karlovac, Alibunar, and then near Zrenjanin). Artesian wells were drilled for water supply. Many of the wells gave hot water which was used in the public baths or spas (Tomić, 2013). In Vojvodina, there is a relatively small number of spas because they were built near the natural mineral springs, which were few in Vojvodina. Only in the second half of the 20th century (from 1949), with the improved techniques of deep drilling, and especially thanks to the drilling of oil and gas (Pašić, 2010), numerous sources of thermal mineral water were discovered in Vojvodina. In 
the period from 1969 to 1996, 73 hydrothermal boreholes were drilled of 62,678.6 $\mathrm{m}$ total depth. Drilling was financed and implemented by NIS - Naftagas (now the company that bears the name of the NIS - Gazprom Neft, as the majority owner of the company is in Russia). Most drilling was done in the 1980s when 45 boreholes were drilled of $34,840 \mathrm{~m}$ total depth. In the period since the nineties the number of drilling for these purposes has been symbolic (only 5), so today there is a total number of 78 boreholes (PSEMR, 2010).

The deepest borehole, of $2520 \mathrm{~m}$, of the total number of 78 boreholes in Vojvodina, is in the Banat near the village of Vrbica (north of Kikinda), which has the warmest water $\left(82^{\circ} \mathrm{C}\right)$. The borehole in Srpska Crnja has a slightly lower water temperature $\left(75^{\circ} \mathrm{C}\right)$, which is located south of the municipality of Kikinda (Tomić and Romelić, 2000). In other boreholes the water temperature ranges from $20^{\circ} \mathrm{C}$ to $72^{\circ} \mathrm{C}$. In most boreholes the temperature is about 30 and $40^{\circ} \mathrm{C}$.

On the territory of the municipality of Kikinda there are six boreholes that have given positive results, i.e. they contain thermal mineral waters which may have wider use. However, decades have passed since the time of drilling and obtaining thermal mineral water in the municipality of Kikinda, and the waters were barely used. The authors have done analysis of the terrain of the wells in the municipality of Kikinda, analysis of thermal mineral waters and gave some solutions what thermal mineral water could be used for in the municipality of Kikinda.

\section{Position of the study area}

The municipality of Kikinda is situated in the north of Serbia, in the northeastern part of the province of Vojvodina, in the territory of Serbian Banat. Banat is one of the three territorial integrities of the province of Vojvodina (Banat, Backa and Srem). In the west its border is the Tisa, in the south the Danube while the borders to the east (with Romania) and north (with Hungary) are intersected with lowland (fig. 1).

The position of the municipality of Kikinda in Vojvodina and in the context of Banat is peripheral. This position was created by drawing the state border with neighboring Romania after World War I, in 1918. The municipal center itself, the city of Kikinda, was developed in a substantial triangle whose vertices are the cities of Szeged, Timisoara and Zrenjanin. Kikinda, although it borders with Romania, in the last decade has not had an open state border crossing with Romania, which was a problem for the population of the settlements which are in the bordering parts of the two countries. State border crossing Nakovo-Lunga was closed in 2004 due to the introduction of visas for citizens of Serbia during the process Romania's integration into the European Union. Since November 
2014, after eleven years, the state border crossing Nakovo-Lunga was reopened. The opening of the border crossing has contributed to improving the situation of the municipality of Kikinda, the transport of passengers and goods on both sides, shortening the time of travelling from Kikinda to Romanian cities. The improved situation of the municipality of Kikinda with the opening of the border crossing Nakovo - Lunga should be utilized and it could significantly affect the economic prosperity of this municipality. This and the exploitation of the sources of thermal mineral waters, which are in the territory of the municipality of Kikinda, could have a significant impact on the economic development of the area.

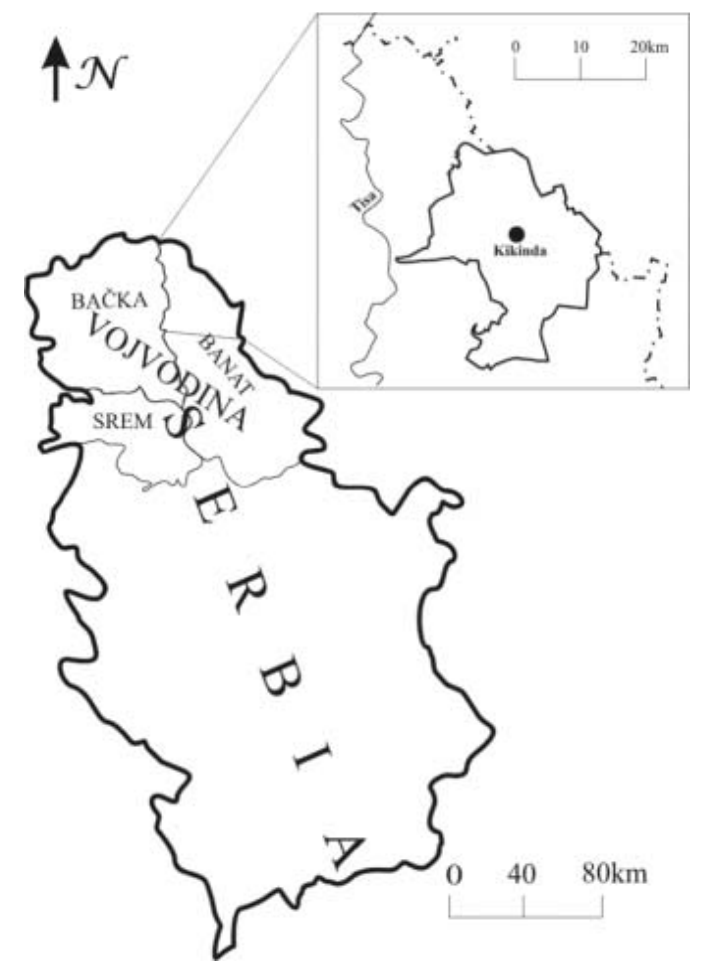

Figure 1. Position of the Municipality of Kikinda in Banat

\section{Material and Methods}

The research area is an area of the northern part of Banat i.e. the municipality of Kikinda, where there are six boreholes with mineral water that can be used. Kikinda belongs to the region of the Pannonian Basin, one of the six hydro geological regions on the territory of Serbia (Krunić and Sorajić, 2013). 
The municipality of Kikinda has the largest number of thermal mineral water boreholes within one municipality in the area of Banat. From a total of 18 wells drilled in the period from 1969 to 2010 on the territory of Banat, six of them are in the municipality of Kikinda. The boreholes are mainly located near settlements or within the settlement (Mokrin, Kikinda and Banatsko Veliko Selo). One borehole is south of the village Mokrin, two are in the vicinity of the town of Kikinda, one south of it, while two borehole in the village Banatsko Veliko Selo. Of these six boreholes, the water borehole in Banatsko Veliko Selo has been used for the longest period of time. The other borehole in the village was conserved immediately after drilling and water testing. The borehole in the village south of Kikinda was also conserved. The other two in Kikinda are out of use, as well as the borehole near Mokrin.

With the help of NIS Gazprom Neft, and the Department of Hydrogeology of the Faculty of Mining and Geology in Belgrade and the Geological Institute of Belgrade, the authors have come up with the necessary data on physical and chemical characteristics of thermo-mineral waters in the municipality of Kikinda. The method of the analysis of the geographical area was used for the assessment of the benefits of the position and physical-geographic characteristics of the municipality of Kikinda because of the different possibilities of using thermal mineral water. A modern hydro geological calculation of Thermal Capacity was used in the study with the formula (1) (Joksimović and Pavlović, 2014)

$$
\mathrm{CAP}(\mathrm{MWt})=\mathrm{FR}_{\max }(\mathrm{kg} / \mathrm{s}) *\left(\text { inlet temp. }\left({ }^{\circ} \mathrm{C}\right) \text { - outlet temp. }\left({ }^{\circ} \mathrm{C}\right)\right){ }^{*} 0,004184
$$

where CAP - thermal capacity and (MWt), FR - flow rate $(\mathrm{kg} / \mathrm{s})$.

The heat flow density was also analyzed, which represents the amount of thermal energy that comes every second through an area of $1 \mathrm{~m}^{2}$ from the Earth's interior to its surface. The calculation is based on the average geothermal gradient and average thermal conductivity of the sediments in locations of hydro geothermal boreholes, which are $1.6 \mathrm{Wm}^{-1} \mathrm{~K}$ for clay and marl, and $2.8 \mathrm{Wm}^{-1} \mathrm{~K}$ for limestone, sands, marls and shale (Milojević, 1989). The obtained values are similar to values in the neighboring area of Hungary (PSEMR, 2010). The heat flow density is calculated using the equation eq. (2)

$$
q=\lambda * \frac{T_{2}-T_{1}}{z_{2}-z_{1}}
$$

where is $\mathrm{q}$ - heat flow $\left(\mathrm{mWm}^{-2}\right), \lambda$ - thermal conductivity $\left(\mathrm{Wm}^{-1}{ }^{\mathrm{o}} \mathrm{K}\right), \mathrm{T}_{1}$ - temperature at a depth $z_{1}, T_{2}$ - temperature at depth $z_{2}, z_{1}$ - the depth at which the temperature was measured $T_{1}(m)$ and $z_{2}$ - the depth at which the temperature was measured $\mathrm{T}_{2}(\mathrm{~m})$.

Geothermal gradient and heat flow density are presented on maps with the method of isoline. 
Data on physical and chemical characteristics of thermal mineral water in the municipality of Kikinda were obtained from NIS Gazprom Neft (formerly Naftagas) that made the testing and drilling of the terrain. Information about the former state and purposes of boreholes were obtained in an interview with experts (geologists, hydro geologists) who worked in the field during the study. The possibilities of using thermal mineral water in the municipality of Kikinda was concluded on the basis of field research, interviews with experts and the authorities in the municipality, as well as on the basis of research in literature.

\section{Discussion}

\section{Hydro geologic features of the study area}

On the territory of Vojvodina, including the territory of municipality of Kikinda we distinguish four hydro geological systems. Each system is characterized by specific lithological, collector, geothermal, stat graphic and hydro chemical characteristics (Udicki, 1985).

The first hydro geological system includes sediments from the surface of the terrain to the upper shelf pier, in other words, quaternary sediments, paludian and upper shelf pier. It has been developed on the entire territory of Vojvodina, except Fruska Gora and Vrsačke hills (Milenić et al., 2014). In lithological terms, its system is made up of different colored clays, sands of different grain-size composition, gravel, coal and sandstone interlayer (Tomić and Romelić, 2000). On the territory of Kikinda this hydro geological system is well developed. It is characterized by relatively large thickness (about 1,500 m), a large number of sandy horizons, large reserves of water, good yield boreholes, high temperatures and good physical and chemical composition of water that enable the use of water for different purposes (Aksin and Milosavljević, 1982).

From the point of appearance of thermal mineral water and the possibility of exploitation, the first hydro geological system on the territory of Kikinda is the most important one because it contains large reserves of thermal mineral water, which has relatively good physical and chemical characteristics that can find suitable application (Śmigić, 1994). The first hydro geological system on the territory of Kikinda municipality reaches to a depth of 1,500 m, however, thermal mineral water can be used to a depth of $1,100 \mathrm{~m}$, because at greater depths there are deposits of oil and gas that make it difficult to exploit mineral water. At a depth of 850 to $950 \mathrm{~m}$ are the best conditions for obtaining thermal mineral water which is found in several boreholes. The deepest boreholes are near the town of Kikinda (Ki-2/H - 1,200 m and Ki-4/H - 1,203 m), while the shallowest borehole is in Banatsko Veliko Selo (Vs-2/H), which depth is $895 \mathrm{~m}$ (tab. 1) (Šmigić, 1994). 
Table 1. Basic information about hydrothermal boreholes in the municipality of Kikinda

\begin{tabular}{|c|c|c|c|c|}
\hline $\begin{array}{c}\text { The name of the borehole } \\
\text { and the city }\end{array}$ & $\begin{array}{l}\text { Year of } \\
\text { drilling }\end{array}$ & $\begin{array}{l}\text { Depth of } \\
\text { borehole } \\
\text { (m) }\end{array}$ & $\begin{array}{l}\text { Capped } \\
\text { interval } \\
\text { (m) }\end{array}$ & $\begin{array}{l}\text { Lithological } \\
\text { composition of the } \\
\text { capped interval }\end{array}$ \\
\hline Šm-1/H (Kikinda) & 1974 & 950 & $865-926$ & sand \\
\hline Mk-1/H (Mokrin) & 1983 & 950 & $886-934$ & sandstone \\
\hline Ki-2/H (Kikinda) & 1984 & 1,200 & $895-970$ & sand \\
\hline Vs-1/H (Banatsko Veliko Selo & 1986 & 925 & $762-846$ & sand \\
\hline Vs-2/H (Banatsko Veliko Selo) & 1987 & 895 & $791-879$ & sand \\
\hline Ki-4/H (Kikinda) & 1987 & 1,203 & $1,089-1,142$ & sand \\
\hline
\end{tabular}

Source: Tonić et al., 1989; Aksin et al., 1991; Šmigić, 1994.

Because of its prevalence and low mineralization of water the first hydro geological system has the greatest economic importance on the territory of the municipality of Kikinda, but also in the whole of Vojvodina. The second hydro geological system has no economic significance due to the low yield and it is difficult to use, because of the high mineralization of water. While the fourth hydro geological system has not been investigated enough, and it is impossible to estimate its importance (Tonić et al., 1989; Aksin et al., 1991; Šmigić, 1994).

\section{Geothermal characteristics of the Municipality of Kikinda}

Geothermal characteristics of the Earth are different from place to place. The territory of Vojvodina, which is an integral part of the Pannonia Basin, has all the hallmarks of specific tectonic units. An important geological characteristic is the small thickness of the Earth's crust, which in Vojvodina is 25.5 to 29 kilometers and the lithosphere, which thickness on the same territory ranges from 60 to 100 kilometers. Small thickness of the Earth's crust and lithosphere in Vojvodina put it among the most promising geothermal areas of Europe. And that is indicated also by the average values of geothermal gradient and heat flow, which are considerably larger than in the area of continental Europe (Milovanović and Boev, 2001).

Geothermal gradient in Vojvodina is determined on the information about the measured temperatures at 78 hydrothermal boreholes and 126 boreholes that were carried out for the research purposes of oil and gas. Based on the obtained values, the geothermal gradients were calculated at depths of 0-500 $\mathrm{m}(0.056$ $\left.{ }^{\circ} \mathrm{Cm}^{-1}\right)$, then at $500-1,000 \mathrm{~m}\left(0.052^{\circ} \mathrm{Cm}^{-1}\right)$ and from 1,000 to $2,000 \mathrm{~m}\left(0.050^{\circ} \mathrm{Cm}^{-1}\right)$. Average values of geothermal gradient in Vojvodina, in the range of 0 to 2,000 $\mathrm{m}$, are $0.0526^{\circ} \mathrm{Cm}^{-1}$, which is considerably more than the average for Continental 
Europe $\left(0.03^{\circ} \mathrm{Cm}^{-1}\right)$ (Dokmanović et al., 2012). In Banat the values of geothermal gradient rise from the southeast, where they are $0.046^{\circ} \mathrm{Cm}^{-1}$, to the north $(0.059$ $\left.{ }^{\circ} \mathrm{Cm}^{-1}\right)$. The southeastern parts of Banat have the lowest value of geothermal gradient in Vojvodina. On the territory of the municipality of Kikinda geothermal gradients are from 0.052 to $0.057^{\circ} \mathrm{Cm}^{-1}$ ), which is shown in fig. 2 (PSEMR, 2010).

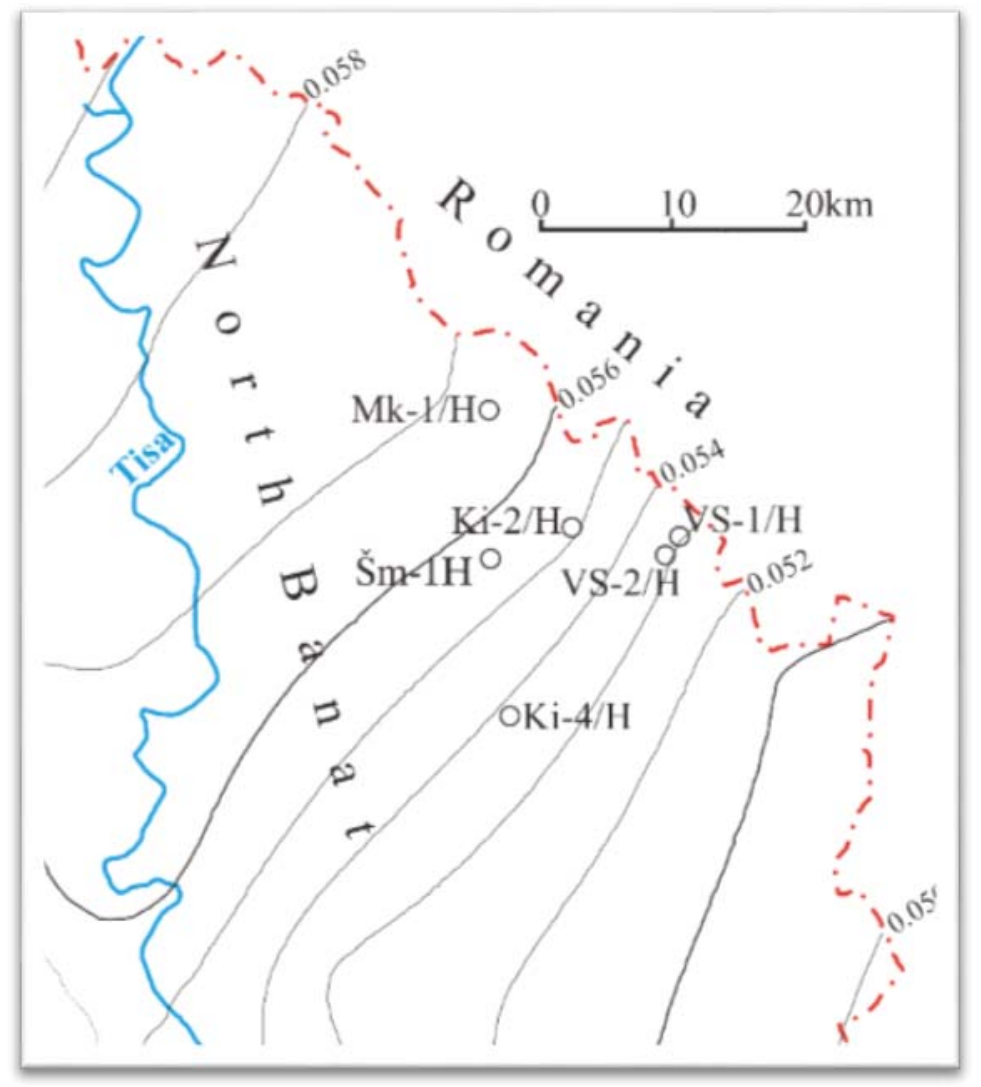

Figure 2. Geothermal gradient in the Northern Banat $\left(\right.$ in $\left.{ }^{\circ} \mathrm{Cm}^{-1}\right)$

Serbia is rich in geothermal water and that is a result of good geological structure and good hydrological and geothermal characteristics of the terrain. The heat flow density is the main parameter for evaluating the geothermal potential of an area. In most of Serbia, the heat flow density is higher than its average value for the continental part of Europe, $87 \mathrm{mWm}^{-2}$. The greatest values of over $100 \mathrm{mWm}^{-2}$ are in the Pannonian Basin (area of Vojvodina), central Serbia and the central part of southern Serbia (Janković, 2009). On the territory of Hungary, which is known for its intensive use of geothermal energy (Balázs, 2012) the heat flow values are between $80 \mathrm{mWm}^{-2}$ and $110 \mathrm{mWm}^{-2}$ (PSEMR, 2010). 
In Vojvodina, the values of terrestrial heat flow are in the range of $84 \mathrm{mWm}^{-2}$ in the southeastern Banat (area of Banat sands) to $111 \mathrm{mWm}^{-2}$ (North Bačka). The biggest heat flow values are in the north of Banat $\left(108 \mathrm{mWm}^{-2}\right)$. The heat flow density, in the municipality of Kikinda, range from $94 \mathrm{mWm}^{-2}$ to $105 \mathrm{mWm}^{-2}$, which is shown in fig. 3. Those terrestrial heat flow values are also in the area of Mount Kopaonik in southern Serbia (Dokmanović et al., 2012) where are the hottest sources of thermal and thermal mineral water in Serbia.

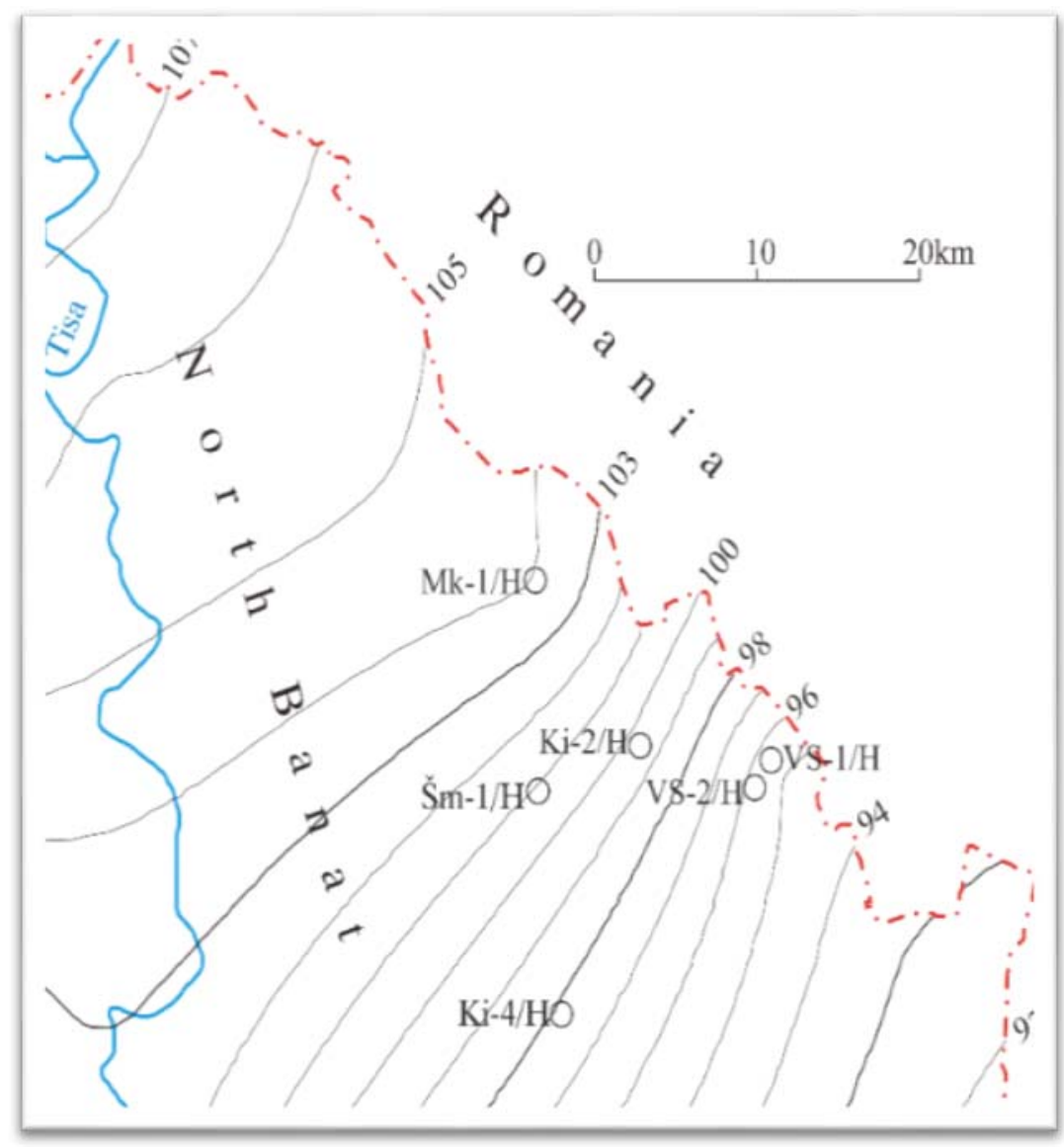

Figure 3. Heat flow on the territory of the Northern Banat (in $\mathrm{mWm}^{-2}$ )

Physical features and characteristics of thermal mineral water on the territory of Kikinda

Physical and chemical characteristics of the thermal mineral water are produced in different geological, hydro geological, geochemical and hydro chemi- 
cal processes in joint action of water, rocks and gases (Milenic and Milankovic, 2010). All thermal mineral waters have certain temperature, salinity, mineralization and $\mathrm{Ph}$ value. In relation to the temperature of the human body all thermal mineral waters can be divided into hypothermia, homoeothermia and hyperthermia. About $48 \%$ of all surveyed thermal waters in Serbia are hypothermic, about $35 \%$ are homoeothermic, and about $17 \%$ are hypothermic (Janjić et al., 2008). On the territory of Vojvodina, from 78 borehole $28 \%$ have hypothermic water, about $12 \%$ are homoeothermic waters, and about $60 \%$ have hypothermic water. According to temperature, all thermal mineral waters in the municipality of Kikinda belong to hypothermic waters because the temperature is higher than $38^{\circ} \mathrm{C}$ or higher than the temperature of the human body. The lowest temperature is at the boreholes of thermal mineral water in Banatsko Veliko Selo $\left(43^{\circ} \mathrm{C}\right.$ and $45^{\circ} \mathrm{C}$ ). Water temperature at two boreholes near Kikinda is $50^{\circ} \mathrm{C}$ and $51^{\circ} \mathrm{C}$, as the water in the borehole in Mokrin. The highest temperature of the water was in the borehole south of Kikinda $(\mathrm{Ki}-4 / \mathrm{H})$ where it was $57^{\circ} \mathrm{C}$, however, which was capped immediately after testing.

General mineralization is an important indicator that is analyzed for the use of water for balneological or other purposes. Active effect of minerals on the human body increases with general mineralization. The lower limit of active effect on human body is usually $1 \mathrm{~g} / 1$, while in some countries it is $2 \mathrm{~g} / 1$ [17]. Mineralization of thermal mineral waters in the municipality of Kikinda range from 1.8 to $3.32 \mathrm{~g} / 1$ (tab. 2). With increasing mineralization the effect on human body also increases. The tendency to deposit lame scale in pipelines and surface installations, aggressiveness on metals and concrete depends on mineralization.

The salinity of water is $0.006 \mathrm{~g} / 1$ to $0.35 \mathrm{~g} / 1$. $\mathrm{PH}$ value in all boreholes is over 7.5, and the biggest value is in Kikinda in boreholes Šm-1/H and Ki-2/C (8.1). Thus, thermal mineral waters in the municipality of Kikinda belong to weak acidic $(\mathrm{pH}=5.5$ to 6.8$)$, neutral $(\mathrm{pH}=6.8-7.2)$ and weak alkaline $(\mathrm{pH} 7.2$ to 8.5) (tab. 2) (Internet 1; Fond NIS Gaspromnjeft). However, the problem is that the $\mathrm{pH}$ values are not measured directly on the well, but in the laboratory after several days of standing water, and the shown values are not the most representative (Milosavljević, 2005).

The total available capacity of all the 78 boreholes, so far explored hydrothermal resources on the territory of Vojvodina is $72.606 \mathrm{MWt}$. The total available capacity of the 18 boreholes in the Banat is $20.175 \mathrm{MWt}$ and in the municipality of Kikinda is 7.248 MWt. The borehole Ki-2/H has the biggest thermal capacity (1.972 MWt), and borehole Šm-1/H has the lowest (0.255 MWt) (tab. 2).

The largest flow is measured at the borehole in Banatsko Veliko Selo (Vs1/H $17.7 \mathrm{l} / \mathrm{s}$ and Vs-2/H 11.61/s) and in Kikinda (Ki-2/H - 15.2 1/s). The flow in the borehole in Mokrin is $10.5 \mathrm{l} / \mathrm{s}$ and the smallest flow is in the borehole Ki-4/H (where it was measured $4.8 \mathrm{l} / \mathrm{s}$ ) and Šm-1/H (2.3 l/s) (tab. 2). 
Table 2. Physical and chemical composition of the thermal mineral waters in the municipality of Kikinda

\begin{tabular}{|l|c|c|c|c|c|c|}
\hline $\begin{array}{c}\text { The name of } \\
\text { the borehole } \\
\text { and the city }\end{array}$ & $\begin{array}{c}\text { Flow rate } \\
(\mathbf{l} / \mathbf{s})\end{array}$ & $\begin{array}{c}\text { Temperature } \\
\left({ }^{\circ} \mathbf{C}\right)\end{array}$ & $\begin{array}{c}\text { Thermal } \\
\text { capacity } \\
(\mathbf{M W t})\end{array}$ & $\begin{array}{c}\text { Mineralization } \\
(\mathbf{g} / \mathbf{l})\end{array}$ & $\begin{array}{c}\text { Salinity } \\
(\mathrm{g} / \mathbf{l})\end{array}$ & $\begin{array}{c}\mathbf{p H} \\
\text { value }\end{array}$ \\
\hline Šm-1/H (Kikinda) & 2.3 & 50 & 0.255 & 3.22 & 0.073 & 8.1 \\
\hline Mk-1/H (Mokrin) & 10.5 & 51 & 1.362 & 3.05 & 0.050 & 7.8 \\
\hline Ki-2/H (Kikinda) & 15.2 & 51 & 1.972 & 2.81 & 0.050 & 8.1 \\
\hline $\begin{array}{l}\text { Vs-1/H (Banatsko } \\
\text { Veliko Selo) }\end{array}$ & 17.7 & 43 & 1.703 & 1.8 & 0.036 & 7.9 \\
\hline $\begin{array}{l}\text { Vs-2/H (Banatsko } \\
\text { Veliko Selo) }\end{array}$ & 11.6 & 45 & 1.213 & 1.92 & 0.006 & 7.5 \\
\hline Ki-4/H (Kikinda) & 4.8 & 57 & 0.743 & 3.32 & 0.35 & 7.7 \\
\hline
\end{tabular}

Sources : (PSEMR, 2010; Aksin et al., 1991; Stojković et al., 2013)

Thermal mineral waters in the municipality of Kikinda chemically are sodium hydro carbonate with certain presence of chlorine (Filipović, 2003). When it comes to gases, methane is present in all waters on the territory of Kikinda. The presence of methane is an economic problem, because it requires the installation of additional equipment for exploitation of water. During the exploitation of thermal mineral waters on their way to the surface there is a drop in pressure and extraction of methane in the form of bubbles, i.e. creation of free methane. If the mineral water is used indoors it can reach concentrations of methane that can form explosive mixtures. In order to avoid this, there is a need of installation of additional equipment to remove methane, which increases the costs of installation and use of thermal mineral water.

\section{Use of thermal mineral water in the municipality of Kikinda}

Thermal mineral waters in some countries have been used for therapeutic purposes for thousands of years. The Romans recognized that potential on the territory of Serbia (Pavlović, 2009). However, the progress of science today has enabled much more methods of use of thermal mineral waters, not only for medicinal purposes. The temperature of thermal mineral water provides certain restrictions on its use. The temperature of $38^{\circ} \mathrm{C}$ to $150^{\circ} \mathrm{C}$ makes the limit to be used directly, while the water (steam) of higher temperature allows the production of electrical energy (Stojković et al., 2013). Direct use includes the use for heating and cooling, for the production in greenhouses of fruit, vegetables and flowers, for the aquaculture, for plant material drying industry, pasteurization and similar, and for heating swimming pools (Gvozdenac, 2011; Milanović, 2006). The 
number of countries in the world that have growth of utilization of geothermal energy is constantly increasing. Most geothermal energy in the world is used for heating, about $60 \%$. About $20 \%$ is used for electricity generation and the remaining $20 \%$ is for industrial use, for heating greenhouses, heating swimming pools, melting snow and on fish farms. In the area of Iceland it is mostly used for heating, $89 \%$ of apartments are heated that way.

Geothermal energy is used only symbolically in Serbia, although it is among richer countries when it comes to geothermal potential. The use of thermal mineral waters is very significant for the future development of the areas where these waters are located, but also for the development of the region, as concluded by the researchers of thermal mineral waters in southern parts of Serbia (Barać and Viras, 2009). It is possible to exploit thermal mineral waters in almost the entire territory of Serbia by means of heat pumps (Andrić, 2014). However, these are just projects which point out the significant possibilities of geothermal energy in Serbia, but which remain unrealized.

Thermal mineral waters in Vojvodina possess above-average geothermal qualities in comparison to the European hydro geological standards. For this reason, this basin is referred to as "the thermal valley" (Klimo, 2011). Nevertheless, only $26 \%$ of the total heat potential of all available boreholes is exploited in Vojvodina, mainly for balneological and tourism purposes (PSEMS, 2010).

The boreholes in the municipality of Kikinda are located near certain facilities (industrial, agricultural, commercial) which could be the potential users of these waters. The boreholes in Mokrin $(\mathrm{Mk}-1 / \mathrm{H})$, Kikinda $(\mathrm{KI}-2 / \mathrm{H})$ and Banatsko Veliko Selo (Vs-1/H) were used for heating commercial facilities and for heating a pig farm. The other borehole in Banatsko Veliko Selo was closed shortly after drilling $(\mathrm{Vs}-2 / \mathrm{H})$, due to a standstill of heating system arising because of certain financial and technical problems, so the user withdrew. The borehole south of Kikinda $(\mathrm{Ki}-4 / \mathrm{H})$ was shut down shortly after the drilling because of large quantities of gas. A test bottling of water from the borehole Šm$1 / \mathrm{H}$ was carried out in order to see whether the water could be used as mineral after cooling. The research and sampling yielded positive results, however a user was not found. The water from these boreholes was also used for heating business and storage facilities of the communal organization " $6^{\text {th }}$ of October". The boreholes were also equipped with a degasifier for extracting methane from water, and with a heating line from the borehole to the location of use. Water to water heat exchangers were installed on the location of use, making the thermal mineral water heat up the water in the radiator system, after which it was deposited in the nearby canal. The project plan was to use the thermal mineral water by means of exchangers for heating the water from the water supply network for sanitary purposes at the same time. However, the user abandoned the plan to use thermal mineral water for financial reasons. 
None of the four open boreholes on the territory of the Municipality of Kikinda has been in use for the last few years. There are several possibilities for the use of thermal mineral water. In addition to the heating of business facilities or pig farms, for which thermal mineral waters from certain boreholes were used for a while, there are other possibilities. In Serbia, thermal mineral waters are mostly used for balneology, sport and recreation. In addition to this, thermal mineral waters in the municipality of Kikinda can be used in agriculture, aquaculture and industry. Initial analyses of the water and its potentials for exploitation for balneological and sport and recreation purposes were performed. This research has yielded positive results, however, substantial investments are necessary in order to use the water, so that the financial reasons are the greatest obstacle to the realization of ideas and projects that were carried out.

It is possible to use thermal mineral waters to heat the glasshouses. Moreover, it is suitable for fish ponds (fig 4). Different sorts of fish require different water temperatures, and by regulating it, it is possible to achieve much larger production compared to the traditional. The use of thermal mineral waters in agriculture for the watering of cultures which have high energy demands is in initial stages (Gajić and Vujadinović, 2009) and requires additional research. On the other hand, watering with thermal mineral waters could also have certain unfavorable consequences for the soil owing to the salt and other substances which would be concentrated in the soil.

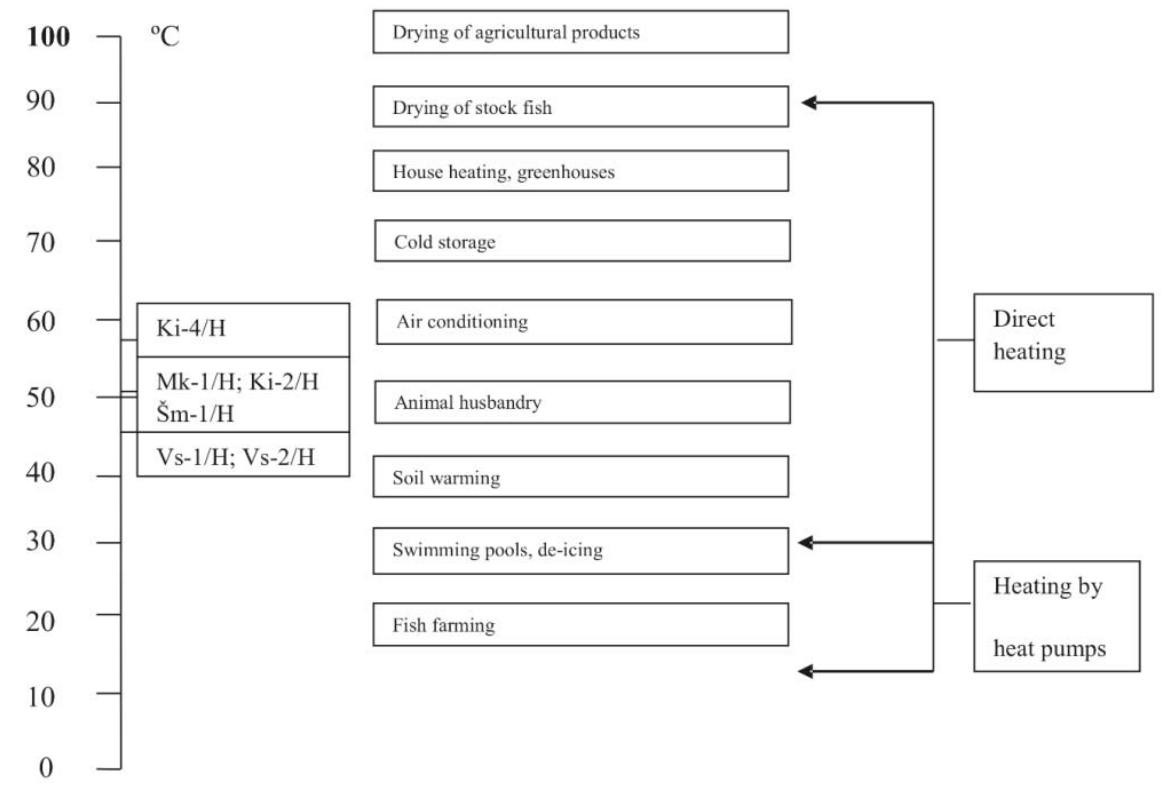

Figure 4. Possible uses of thermal mineral water, depending on the temperature a modified Lindal's diagram (Milenić et al., 2015) 
The possibilities for using thermal waters in the industry of Kikinda itself are numerous, depending on the type of the geothermal energy available and the required temperature. They can be used for: drying, evaporating, distillation, cooling, baking, washing, coloring, process heating and the heating of industrial facilities. Drying by means of hot water has an especially wide range of application in industry Mitić et al., 2007). Heated air can be used to dry agricultural products (Milojević and Martinović, 1996; Ružičić et al., 2013). Certain private-owned companies were interested in the borehole in Banatsko Veliko Selo (Vs-2/H) and their intention was to build a spa. However, the Municipality did not agree to this. There were also intentions on part of the local community to build a spa or heat glasshouses, but there aren't enough financial means for the implementation of these projects.

Due to unfavourable impacts on the soil, it is necessary to construct watertight canals or new boreholes which would be used to insert used water (Farsang et al., 2015; Milenić et al., 2015). This makes the use of thermal mineral waters more expensive, which is one of additional reasons this natural potential is so poorly used in the municipality of Kikinda.

The boreholes in the municipality of Kikinda have a great geothermal potential. Their exploitation in agriculture and for heating water is very lucrative. This area has been explored for the most part and it has been found to be very rich in geothermal energy, which should be used properly (Institute of Energy, Process Technics and Environmental Protection). However, the State has remained barely interested in reactivating the boreholes with thermal mineral water which have already been in use, or activating those that have not been used at all. Private-owned companies have not expressed any particular interest in the topic, so this significant natural potential must wait for better times (Košić et al., 2011).

\section{Conclusion}

Thermal mineral waters of Vojvodina can be an important factor of regional development, which is also characteristic for the Northern Banat area, especially for the Municipality of Kikinda, which has the largest concentration of thermal mineral boreholes in Banat. The temperature of these waters makes possible their direct application. The increased gas factor is causing all the boreholes to effuse by themselves, which is favorable on the one hand, because no additional investments are required to bring the water to the surface. Whereas, on the other hand, it is necessary to construct degasifiers in order to relieve the water from the presence of gases, especially methane, which is present in larger quantities than any other gas. The natural conditions for the use of thermal mineral water 
are very favorable. A lowland area, favorable climate and fertile soil enable a wide range of application in agriculture, especially for heating glasshouses and greenhouses, for heating cattle farms and fish ponds. In addition to this, the proximity of a larger town (Kikinda) can also enable the application in industry, but also for heating business facilities and residential units. On the territory of Serbia, including Vojvodina, thermal mineral waters are used mostly for balneological and sport and recreational purposes. The first physical and chemical analysis of thermal mineral waters in Kikinda area, which were carried out in late 1980s and early 1990s, showed that these waters are suited for balneological and sport and recreational purposes.

By using thermal mineral waters from three boreholes alone (boreholes that were in exploitation for a while), the significant amountsof crude oil was saved. However, in order to enable the application of thermal mineral waters in the municipality of Kikinda on a larger scale, it is necessary to make up a registry of potential users, but also to come up with design solutions for the application in balneology, industry, agriculture, sport, recreation and tourism. It is necessary to provide financial means, and to make the procurement of required documents for the application of thermal mineral waters less complicated, i.e. it is necessary to simplify the administrative procedure which has to be followed in order to be able to use the thermal mineral waters.

\section{Acknowledgements}

The authors would like to express their sincere thanks to the Ministry of Education, Science and Technological Development, Republic of Serbia - Project No. 176020, and to the Provincial Secretariat for Higher Education and Scientific Research of the Vojvodina Province, Republic of Serbia - Project No. 142-451-2490/2017-01, for their financial support.

\section{References}

Aksin, V., Marinović, Đ., \& Vugrines, J. (1991). Exploration and production of oil crude oil and gas in Yugoslav part of Pannonian basin. In: Geodynamic evolution of the Pannonian Basin. Belgrade, 309-329.

Aksin, V., \& Milosavljević, S. (1982). Geothermal energy - research and application worldwide and in Yugoslavia, with special reference to Vojvodina. Dubrovnik: JUGOMA. (in Serbian)

Andrić, N. (2014). Geothermal energy and the possibilities for its application in Serbia. Termotehnika, 40(1-2), 47-54. (in Serbian) 
Balázs, K. (2012). Analysis of Changes in the Utilization of Thermal Water and Geothermal Energy in the North Great Plain Region (Northeastern Hungary). Geographica Pannonica, 16(2), 56-71.

Barać, M., \& Viras, N. (2009). Heat exchange calculation of geothermal waters of Josanicka Spa in the plastic greenhouse pilot project realization. Journal of Applied Engineering Science, 7(25), 77-85.

Belij, M., \& Belij, S. (2009). Protection of spas, with a special reference to Ribarska Banja. Zaštita prirode, 60(1-2), 567-576. (in Serbian)

Bubalo, M., \& Bogdanović, Ž. (2000). The possibilities for application of thermal mineral water in Indjija. Turizam, 4, 57-58 (in Serbian).

Dokmanović, B.P., Krunić Ž.O., Martinović, K.M., \& Magazinović, M.M. (2012). Hidrogeothermal resources in spa areas of Serbia - Main properties and possible improvement of use. Thermal Science, 16(1), 21-30.

Farsang, A., Tóth, M.T., \& Balog, K. (2015). Environmental risks of waste thermal water disposal: long-term effects of thermal water seepage on different soil types. Environmental Engineering and Management Journal, 14(5), 1217-1229.

Filipović, B. (2003). Thermal and thermal mineral waters of Serbia. Belgrade - Vrnjacka Banja: The Association of spa and health resorts of Serbia, The Institute of Hydrogeology of the Faculty of Mining and Geology in Belgrade. (in Serbian)

Fond NIS Gaspromnjeft.

Gajić, M., \& Vujadinović, S. (2009). The layout and the possibilities for application of thermal and thermal mineral waters in Mačva. Bulletin of the Serbian Geographical Society, LXXXIX, 115-133.

Gvozdenac, D., Nakomčić-Smaragdakis, B., \& Gvozdenac-Urošević, B. (2011). Renewable Energy Sources. Novi Sad: FTN Izdavaštvo. (in Serbian)

Institute of Energy, Process Technics and Environmental Protection (2005). The possibilities for application of the potential of geothermal waters in Vojvodina, Novi Sad: Faculty of Technical Sciences. (in Serbian)

Inventory of NIS Gaspromnjeft (2005). Retrieved from http://www.psemr. vojvodina.gov.rs/images/Studije/Geotermalna-energija/Mogucnosti_ koriscenja_energetskog_potencijala_geotermalnih_voda_u_AP_Vojvodini_-_ prilog_2_-_2005.pdf.

Ivić, M., Andrin, O., \& Jorović, B. (2002). Geothermal energy resources in Serbia and the possibilities of their application. Časopis za procesnu tehniku i energetiku $u$ poljoprivredi/PTEP, 6(3-4), 92-96. (in Serbian)

Janjić, M., Komatina, M., \& Nikić, Z. (2008). Thermal waters and spas of Serbia. Belgrade: Elit-Medica. (in Serbian)

Janković, V. (2009). Geothermal energy: how to use the hidden potential of Serbia. Belgrade: Jefferson Institute. (in Serbian) 
Joksimovic, M., \& Pavlovic, M. (2014). Conditions and possibilities of direct utilization of Thermal-mineral waters in Raska region, Serbia. Renewable and Sustainable Energy Reviews, 32, 107-113.

Klimo, A. (2011). The mineral waters of spas in the Pannonia basin. Serbian Archives of Medicine, 139(3-4), 203-208. (in Serbian)

Kocsis, I., \& Kiss, J. (2015). Renewable energy consumption, R\&D and GDP in European Union countries. Environmental Engineering and Management Journal, 13(11), 2825-2530.

Košić, K., Pivac, T., Romelić, J., Lazić, L., \& Stojanović, V. (2011). Characteristics of the thermal-mineral waters in Backaregiona (Vojvodina) and their exploitation in spa tourism, Renewable and Sustainable Energy Reviews, 15, 801-807.

Krunić, O., \& Sorajić, S. (2013). Balneological classification of mineral waters of Serbia. Serbian Archives of Medicine, 141(1-2), 72-80. (in Serbian)

Lukić, T., Ćurčić, N., Bjeljac, Ž., \& Penjišević, I. (2014). Exploration and Exploitation of Mineral Waters and their Influence on the Regional Development - Case Study of a Vrnjacka Spa (Serbia). European Researcher 69(2-2), 382-400.

Milanović, D.P. (2006). Development of the heating system using geothermal energy. Thermal Science, 10(4), 211-218.

Milenić, D., Milanković, Đ., Vranješ, A., Savić, N., \& Doroslovac, N. (2015). Chemical composition of the thermomineral waters of JošaničkaBanja Spa as an origin indicator, balneological valorization and geothermal potential. Chemical Industry, 69(5), 537-551.

Milenic, D., \& Milankovic, Đ. (2010). The genesis of thermal mineral waters of Josanicka spa (Central Serbia). Zaštita prirode, 61(1), 167-183. (in Serbian)

Milenic, D., Milivojevic, M., Krunic, O., \& Vranjes, A. (2014). Hydrogeothermal resources as a development factor in Serbia. Retrieved from https://www.sanu. ac.rs/Novosti/2014GeoTerVode3VRANES.pdf. Accessed 14 May 2016.

Milojević, M. (1989). Assessment of geothermal resources of the territory RS outside SAP. (Unpublished Ph.D. thesis). Belgrade: Faculty of Mining and Geology. (in Serbian)

Milojević, M., \& Martinović, M. (1996). Geothermal resources in the region of Kolubara, Mačva and Podrinje. Belgrade: Geološki zavod Gemini. (in Serbian)

Milosavljević, S. (1994). Geothermal potentials of the Pannonian basin in Serbia and the possibilities of application. Novi Sad: DIT. (in Serbian).

Milosavljević, S. (2005). Geothermal resources of Vojvodina with special emphasis on thermal waters and spas - Spas of Vojvodina. Novi Sad: Assembly of the Autonomous Province of Vojvodina. (in Serbian)

Milovanović, D., \& Boev, B. (2001). Earth, plate tectonics, magmatism. Belgrade: Nauka. (in Serbian) 
Mitić, N., Stojiljković, D., Stojiljković, S., \& Đurović-Petrović, M. (2007). The usage of geothermal water of Sijarinska spa for drying carrot. Časopis za procesnu tehniku $i$ energetiku u poljoprivredi / PTEP, 11(1-2), 70-71. (in Serbian)

Nakomcic-Smaragdakis, B., Dvornic, T., Cepic, Z., \& Dragutinovic, N. (2016). Analysis and possible geothermal energy utilization in a municipality of Pannonian Basin of Serbia. Renewable and Sustainable Energy Reviews, 59, 940-951. doi:10.1016/j.rser.2015.12.337.

Pašić, M. (2010). Quality of underground water and hydrogeological situation caused by oil exploitation in the area of Kikinda. Bulletin of the Serbian geographical Society, XC(1), 73-92.

Pavlović, M., Radivojević, N., \& Lazić, J. (2009). Sustainable Development of spa tourism in Serbia. Industrija, 37(2), 37-57. (in Serbian)

PSEMR (2010). Geothermal atlas of Vojvodina. Belgrade - Novi Sad: Provincial Secretariat for mineral resources. (in Serbian)

PSEMS (2010). The energy balance of the Autonomous Province of Vojvodina - Part of the energy balance of the Republic of Serbia for 2011. Novi Sad: Provincial Secretariat for mineral resources. (in Serbian)

Radičević, B., Vukić, Đ., \& Rajaković, N. (2008). Status and perspectives of renewable energy sources in Serbia. Poljoprivredna tehnika, XXXIII(3), 89-98. (in Serbian)

Ružičić, L., Kostadinović, L., Gligorević, K., \& Oljača, M. (2013). The application of geothermal energy in agriculture. Poljoprivreda i šumarstvo, 59(2), 91-104. (in Serbian)

Šmigić, A. (1994). Thermal mineral waters in Kikinda area. Novi Sad: Faculty of Sciences. (in Serbian)

Stojković, S.J., Marinković, G.H., \& Papić P.J. (2013). The analysis of the geothermal energy for power generation in Serbia. Thermal Science, 17(4), 969-976.

Tomić, N. (2013). The use of Geothermal Energy Resources in the Tourism Industry of Vojvodina (Northern Serbia). European Researcher, 42(2-3), 443-454.

Tomić, P., \& Romelić, J. (2000). Features and Exploitation of Thermal-Mineral Water in the Yugoslav Banat. Geographica Pannonica, 4, 26-30.

Tonić, S., Milosavljević, S., Vidović, S., \& Agatonović, V. (1989). Results of exploration and utilization of geothermal water in Vojvodina. Journal of YU Committ of the World Petroleum Congress. Nafta, 40(10), 593-600. (in Serbian)

Udicki, A. (1985). The geothermal potential of the first hydro geological system in the region of Kikinda. Novi Sad: NIS Naftagas. (in Serbian) 